\title{
COMPETITIVENESS OF DAIRY INDUSTRY PRODUCTS OF UKRAINE: CURRENT STATE AND PROSPECTS*
}

\author{
Mariia Ishchenko \\ senior lecturer \\ Arthur Golikov International Economic Relations Department \\ V.N. Karazin Kharkiv National University \\ Svobody sq., 6, Kharkiv, Ukraine, 61022 \\ e-mail: lazarchuk@karazin.ua \\ ORCID: http:/ / orcid.org/0000-0003-4275-9579 \\ Danylo Honchar \\ student \\ Arthur Golikov International Economic Relations Department, \\ V.N. Karazin Kharkiv National University \\ Svobody sq., 6, Kharkiv, Ukraine, 61022 \\ e-mail: gonchar.danylo@gmail.com \\ ORCID: http:/ / orcid.org/0000-0003-4292-6322
}

\begin{abstract}
The article considers the current state, trends and problems of development of the dairy industry of Ukraine in modern conditions. The subject of the research in the article is the competitiveness of Ukrainian dairy products in global markets. The goal is an identification of comparative advantages of the dairy industry of Ukraine and identified prospects for its further development. The purpose of the article is to find out the current state and dynamics of production, world prices, demand, exports of dairy products in Ukraine and the world, to determine the comparative advantages of Ukraine in the dairy industry based on the calculation of the Balass index, to review the environmental aspect of the industry. General scientific used research methods: system analysis - to determine the competitiveness of the dairy industry of Ukraine; historical method - to track trends in the global and Ukrainian dairy market; correlation analysis - to determine the interaction of price relations in the domestic market, statistical method - to reflect quantitative indicators, etc. The following results were obtained: based on the study revealed trends in reducing production and exports of dairy products, identified comparative advantages of the dairy industry of Ukraine in a larger regional territory of European markets and proposed ways of further development in accordance with current challenges in the world. Conclusions: the Ukrainian dairy industry is able to compete in world commodity markets, promising areas for export expansion may be Kazakhstan, Moldova, Kyrgyzstan, the Middle East. Given the overall reduction in the capacity of the dairy industry in Ukraine, producers propose to focus on intensifying production and implementing new technologies, taking into account the environmental component.
\end{abstract}

Key words: dairy industry, export, competitiveness, milk production, dairy industry, comparative advantages, environment.

Formulation of the problem. The dairy industry is one of the leading sectors of the national economy, which provides the population with food. It began to develop in ancient times, and still demand for dairy products is growing, primarily due to population growth.

For Ukraine, dairy production has been a traditionally developed sector, but in recent years total production has been steadily declining, dairy prices were constantly rising, and it's getting harder and harder to export them. That is why we find it necessary to study current situation on the dairy market in Ukraine and determine the prospects for its further development.
Analysis of recent research and publications. The study of the functioning of the dairy market in Ukraine and other countries is devoted to the work of many authors. In particular, V. Dzhedzhula, I.Yepifanova and M. Dziubko analyse the efficiency of milk production and conclude on the need to diversify and increase of production which should make studied enterprise more competitive [3]. T. Mostenska emphasized that competitiveness of dairy products is directly depends on the prices and level of income in the country. It was stated that government should care not only about the stability of prices, but look into social sphere [7].

\footnotetext{
* Cite as: Ishchenko M., Honchar, D. (2021). Competitiveness of Dairy Industry Products of Ukraine: Current State and Prospects, The Journal of V. N. Karazin Kharkiv National University. Series: International Relations. Economics. Country Studies. Tourism. 13, 89-98. https://doi.org/10.26565/2310-9513-2021-13-09
} 
N. Skopenko and A. Bovkun analyze Ukrainian dairy market and find that dairy industry has no homogeneous dynamic. Production of milk is constantly falls, but e.g. sour milk and ice cream have recovered last years [8].

Yu. Tarasova proposes to unite small producers in cooperatives and emphasizes the necessity for a state support for the industry [10]. Khvorost T. V. is confident that Ukraine should find new prospective markets and use modern foreign technologies to stay competitive on the global market [11]. Cherednichenko and O. Pashchenko propose several points, in particular optimization of farms and processing industry relations, improvement of the price mechanism formation of the dairy market and improvement of quality and range of dairy products [12].

F. Frick and J. Sauer study dairy market in Germany. They hypothesize that both extreme output price levels and market deregulation fostered efficient reallocation of production resources, but it wasn't confirmed in the result of the research [17].

L. Pronko and T. Kolesnik highlighte the need of improving the qualifications of specialists of the industry, including an education system that will ensure the stability and reliability of production [19]. O. Varchenko and V. Radko emphasize a system of quality management and product safety should be established [23].

The purpose of the article is to identify the comparative advantages of the dairy industry of Ukraine and identify prospects for its further development, considering the environmental aspect of the issue.

Research results. As it is known, the dairy industry includes enterprises for the production of butter, whole milk products, canned milk, milk powder, cheese, brynza cheese, ice cream, casein and other dairy products [9].

According to FAO, the largest dairy producer in the world today is India, followed by the United States, Brazil, Pakistan and China [16].

To review the dynamics of world prices for dairy products, we use the food price index, which is calculated by the Food and Agriculture Organization of the United Nations (Fig. 1). The index consists of 5 sub-indices - dairy products, vegetable oils, cereals, meat and sugar, issues with recalculation are updated monthly.

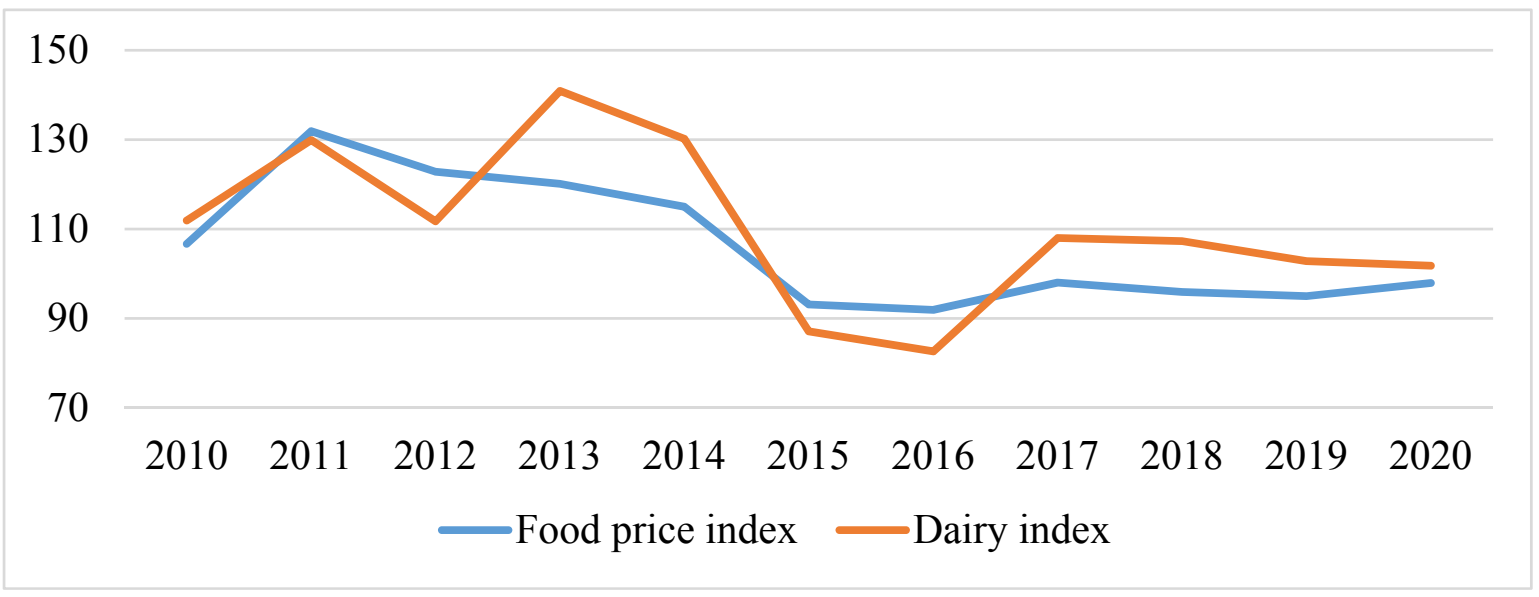

Fig. 1. Index of food and dairy products prices (2010-2020) [6]

According to the Food and Agriculture Organization, milk prices have fluctuated somewhat over the past decade. 2015-2016 were exceptional as a result of the global crisis, after which demand began to recover. Even in the special year 2020, this product remained one of the main products on world markets, despite the fact that milk prices are consistently high. This situation is explained by stable demand, as milk is one of the main products used in various sectors of the food industry, and its indispensability in human nutrition.

To verify the assertion of a consistently high world demand we consider the dynamics of dairy exports to the largest regions (Europe, Asia, Africa and America) (Fig. 2).

From this graph we can see that dairy exports are growing except in Africa. Production and exports to European countries are projected to be 90 high. The African market is focused primarily on meeting their own demand, and the American market is developing less dynamically due to imports of cheaper dairy products from Asia. It can be assumed that the center of production and, as a result, the export center will soon move to Asia, because European countries are actively concerned with environmental issues. And the dairy industry is polluting the environment [5], which is why Europe is likely to start reducing its own production in the near future and, as a result, will be forced to import dairy products.

In Ukraine, the actual milk production is much lower than the required consumption, which affects the quality of food. The increase in milk production is constrained by the low profitability and the fact that the majority of the population of Ukraine cannot buy the required amount of dairy products due to its high cost. 


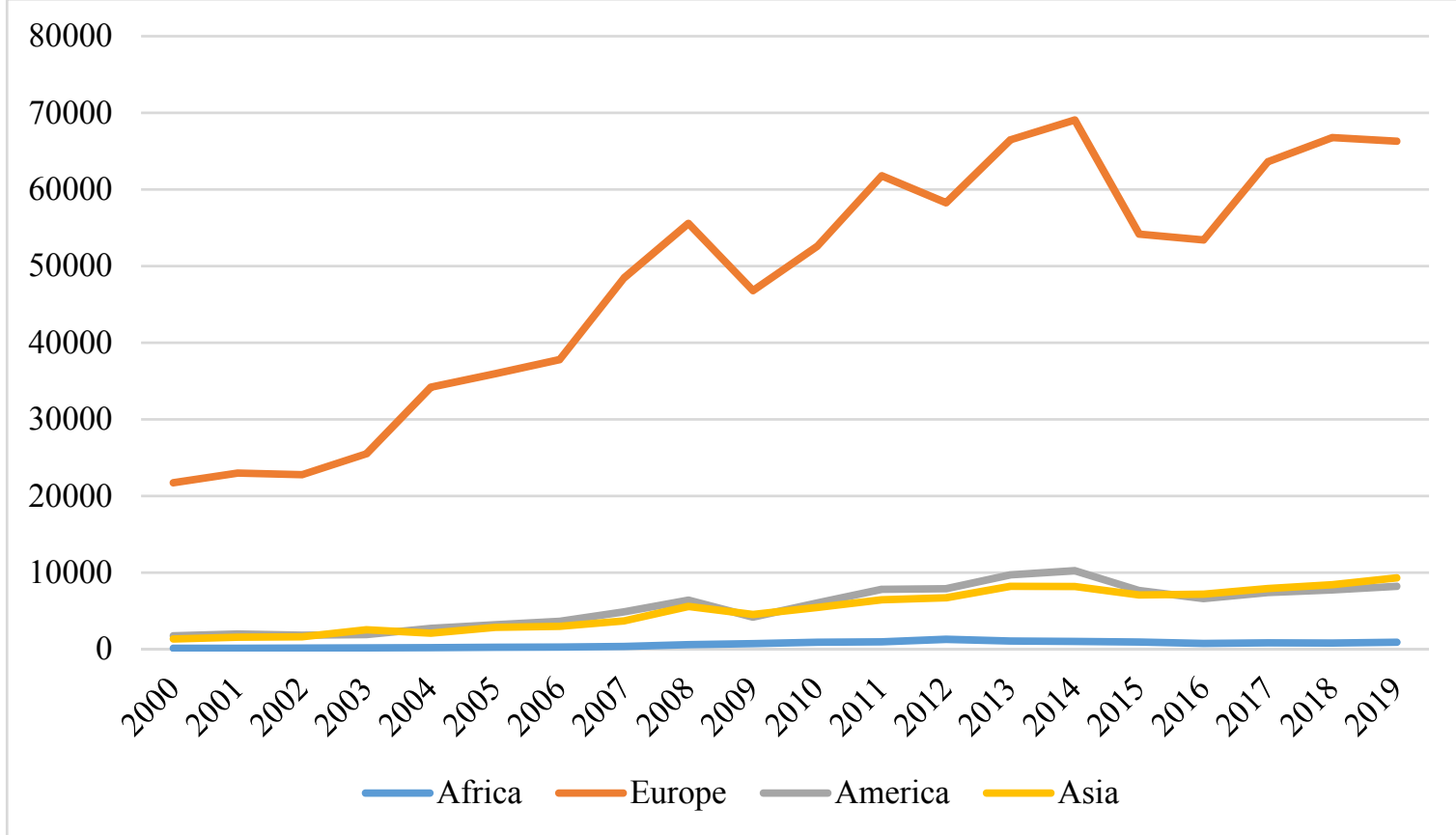

Fig. 2. Exports of dairy products (million US dollars) [16]

Meanwhile, according to the State Statistics Service, in Ukraine since 2016, exports of dairy products are constantly growing (Fig. 3), while livestock is declining. Cheese production remains virtually unchanged due to low profitability. The growth of dairy exports can be explained by the fact that Ukrainian producers have followed the path of intensifying production. First of all, genetic engineering is used, although the quality of feed also contributes to the quantitative increase in milk yield.

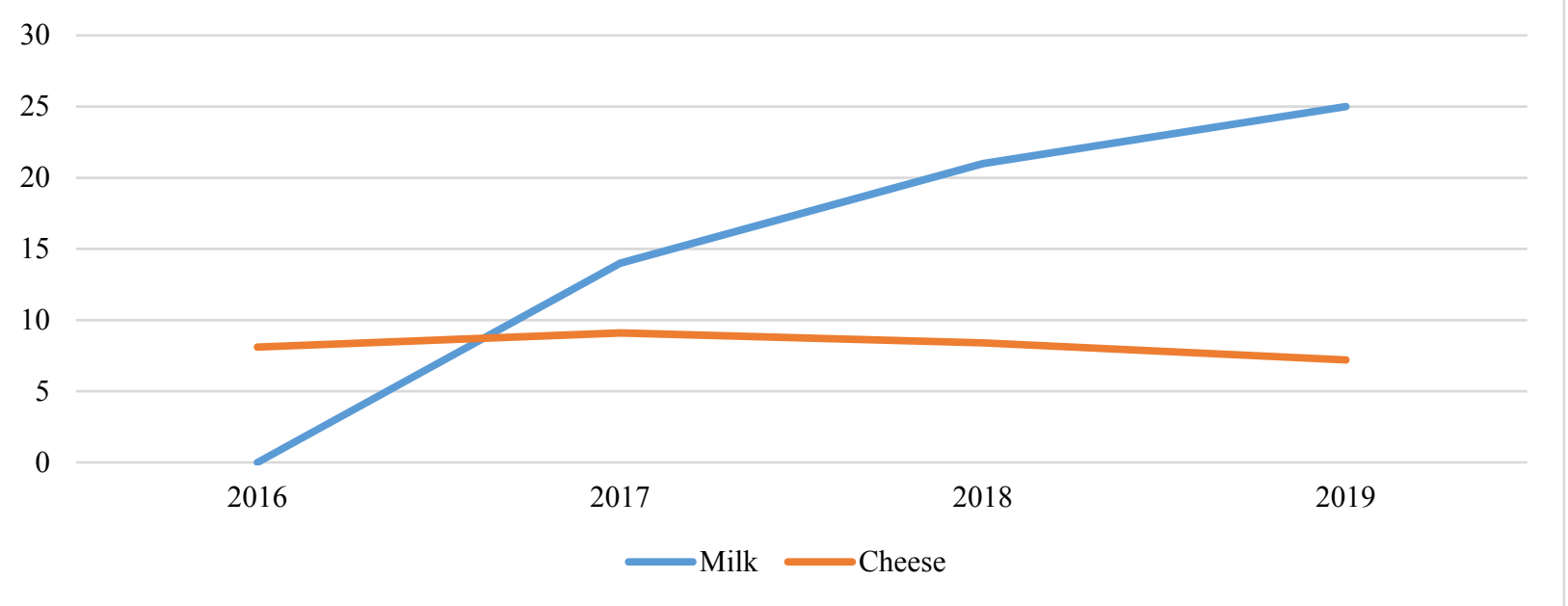

Fig. 3. Export of milk and cheese from Ukraine 2016-2019, thousand tons [2]

Despite the fact that Ukraine has chosen crop production as its main specialization, animal husbandry in our country is focused primarily on dairy cattle. In our opinion, this is due to tough competition with European meat products (including Polish). Cheese production is mostly focused on covering domestic demand, which is currently being met, including due to imports [20]. The signed free trade agreement with the EU has made the Ukrainian cheese market unprotected, but the positive point is the abolition of duties on some cheese [4]. In monetary amount, according to the OEC, in 2018
Ukraine exported cheese worth 25.8 million US dollars. The largest consumers of Ukrainian cheese were Kazakhstan, Moldova, Egypt, Kyrgyzstan [18].

We consider it necessary to note that according to 2018 , cheese exports increased compared to 2017 , but the analysis of a longer period of time shows a sharp decrease in cheese exports - almost 10 times (Fig. 4). This situation is explained, first of all, by the devaluation of the Ukrainian currency against the dollar in 2014 and the contraction of markets after the severance of relations with Russia. 


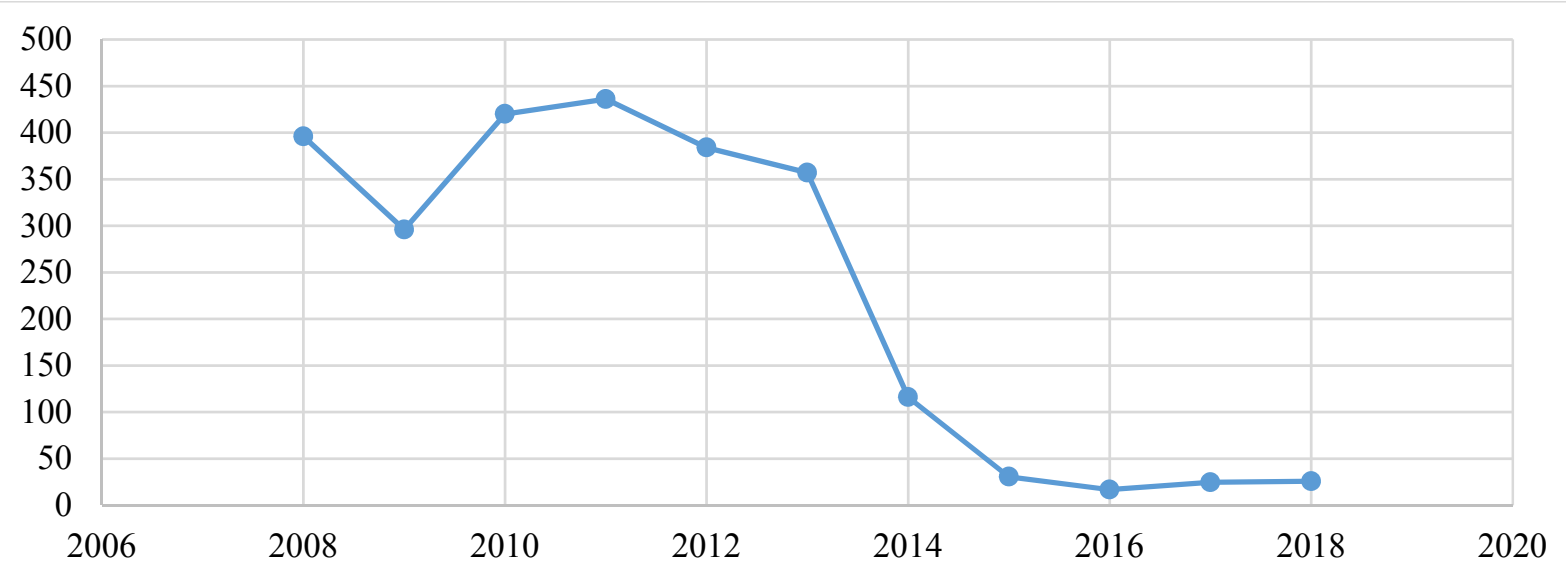

Fig. 4. Export of cheese (million US dollars) [20]

To identify the comparative advantages of Ukraine in the dairy industry in the main regional markets of the world, the Balassa index was calculated (Table 1).

Calculation of the Balass index for the dairy industry of Ukraine

Table 1

\begin{tabular}{|l|l|l|l|l|c|}
\hline \multirow{2}{*}{ Year } & \multicolumn{5}{|c|}{ Region/Balass index } \\
\cline { 2 - 6 } & \multicolumn{1}{|c|}{ Africa } & \multicolumn{1}{c|}{ Europe } & America & Asia & World \\
\hline 2013 & 2,481512142 & 0,490953705 & 1,453909061 & 4,1908872 & 0,297066829 \\
\hline 2014 & 4,460172872 & 0,845738682 & 2,509126949 & 7,609781844 & 0,516379642 \\
\hline 2015 & 3,26251484 & 0,89781076 & 7,005995605 & 3,134889717 & 1,826567094 \\
\hline 2016 & 2,760146663 & 0,669576435 & 2,403983717 & 5,302170635 & 0,406444708 \\
\hline 2017 & 3,478983763 & 0,709932982 & 2,673024161 & 6,144826087 & 0,447853994 \\
\hline 2018 & 2,575084229 & 0,474277472 & 1,749675857 & 4,005512614 & 0,967924987 \\
\hline 2019 & 1,836931559 & 0,384874468 & 1,355208934 & 2,924930603 & 0,236831128 \\
\hline
\end{tabular}

Developed by the authors based on materials: $[1,2,9,14,16,21]$

As we can see, the Ukrainian dairy industry has relative comparative advantages on world markets. We have the greatest advantages over Asian countries, which is due primarily to the radically different specialization of Asian countries. In general, Ukraine is able to compete in most regional markets, except for the European one. After all, it is Europe that remains the world's "hegemon" in dairy exports.

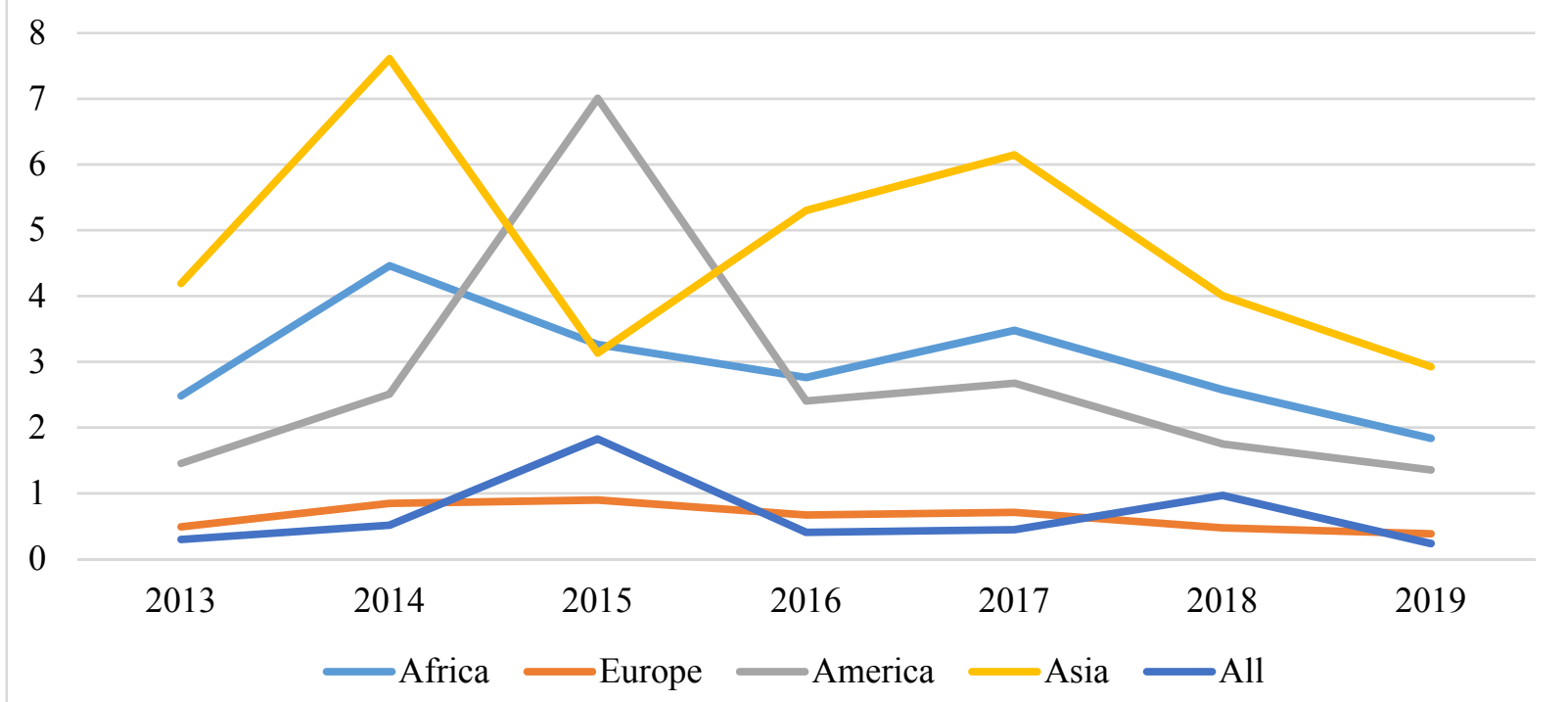

Fig. 5. Comparison of indicators of competitiveness of the dairy industry of Ukraine, Balass index $[1,2,9,12,15,16]$

From the dynamic built on the basis of the received calculations (table 1) it is clear that Ukraine loses competitive advantages in export of dairy products. In our opinion, the situation can be improved by intensification through the renewal of the main dairy breeds in Ukraine to 
more modern and productive ones, and as a result the production volumes will be increased.
As mentioned above, in recent years, the livestock that provides raw materials to the dairy industry of Ukraine is constantly declining (Fig. 6).

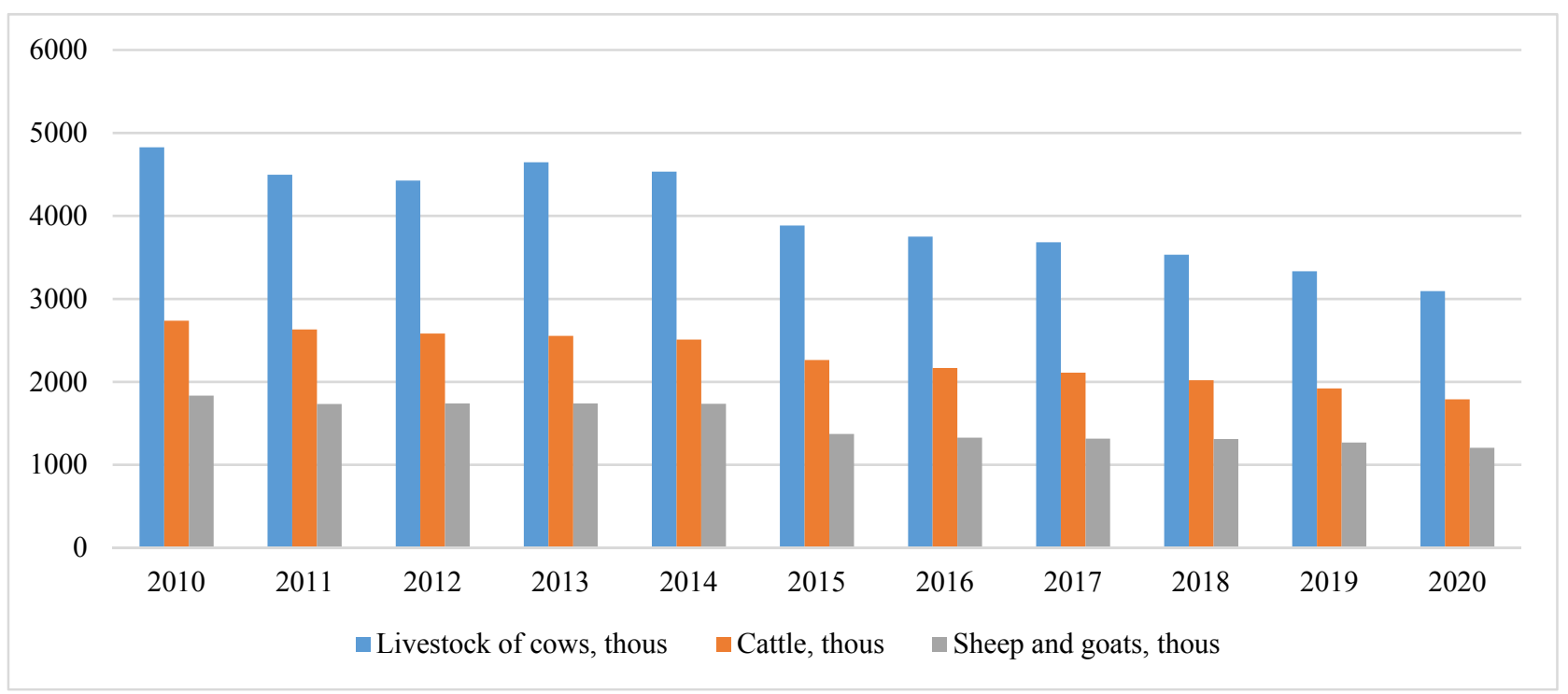

Fig. 6. Livestock in Ukraine [2]

This trend shows that the livestock is declining every year, with the percentage of cattle suffering the most, and the number of sheep and goats is also declining, but at a slow pace. Periods of reduction in the number of sheep and goats were replaced by periods of recovery. For example, between 2007 and 2011, the population increased by 200,000 , and during 2011-2014 it remained at the same level. The recession in 2015-2020 is not critical, but due to the crisis related to the spread of coronavirus disease, rising feed prices and lack of government support for the industry, recovery in the coming years is questionable.

The reduction in livestock has directly affected the Ukrainian dairy market. In order to check its influence we can compare the dynamics of prices for dairy products (Fig. 7) with production volumes
(Fig. 8). It is true that such an analysis does not consider inflation, but the correlation between the two will help to understand how much the reduction in livestock affects the selling prices of enterprises.

We propose to conduct a correlation analysis to track the relationship between market prices and production volumes. The correlation coefficient is calculated by this formula:

where:

$$
r=\frac{\frac{1}{n} \times \Sigma|X-\bar{X}| \times|Y-\bar{Y}|}{\sigma_{x} \times \sigma_{y}}(1),
$$

$\mathrm{r}$ - correlation coefficient;

$\mathrm{n}-$ number of periods (years);

$\sum|X-\bar{X}| \times|Y-\bar{Y}|$ - the sum of the central deviations;

$\sigma_{x}$ i $\sigma_{y}-$ standard deviations.

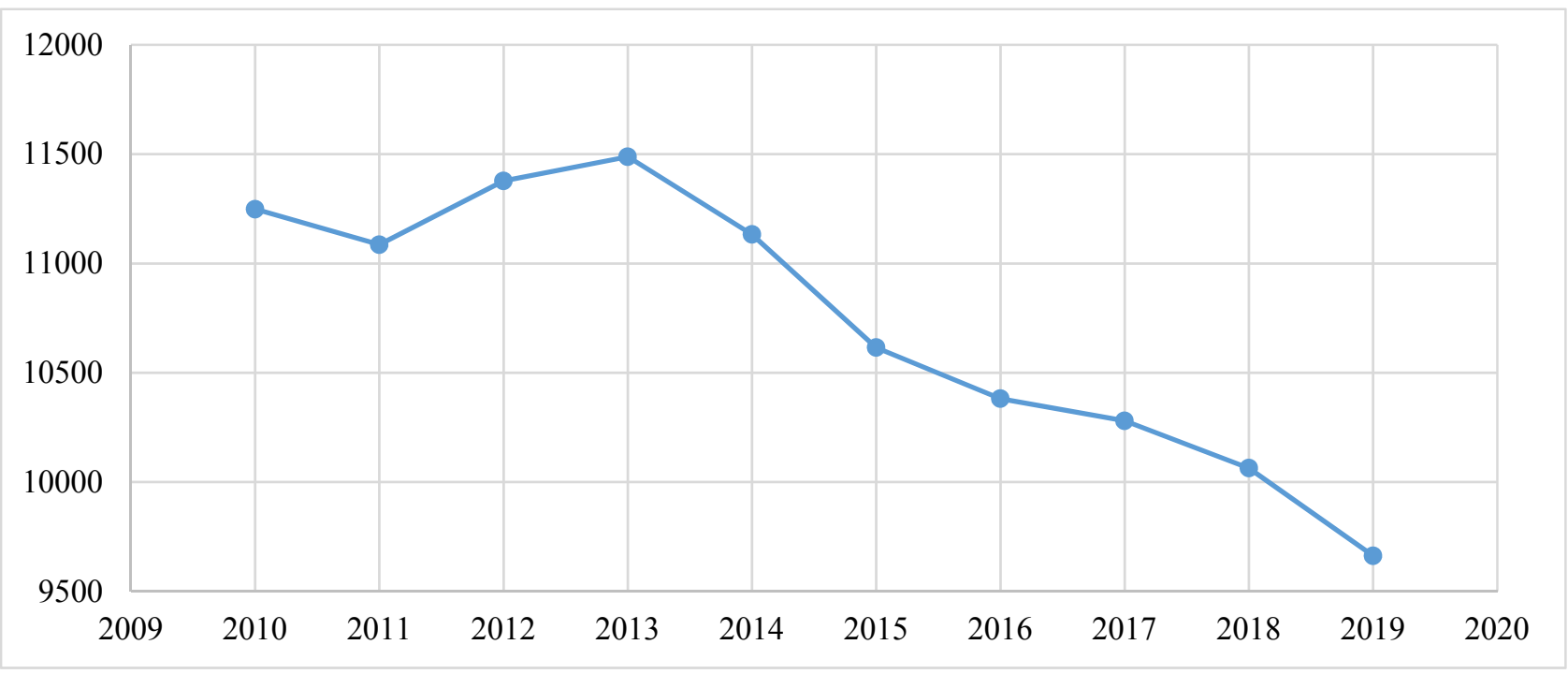

Fig. 7. Milk production, thousand tons [2] 


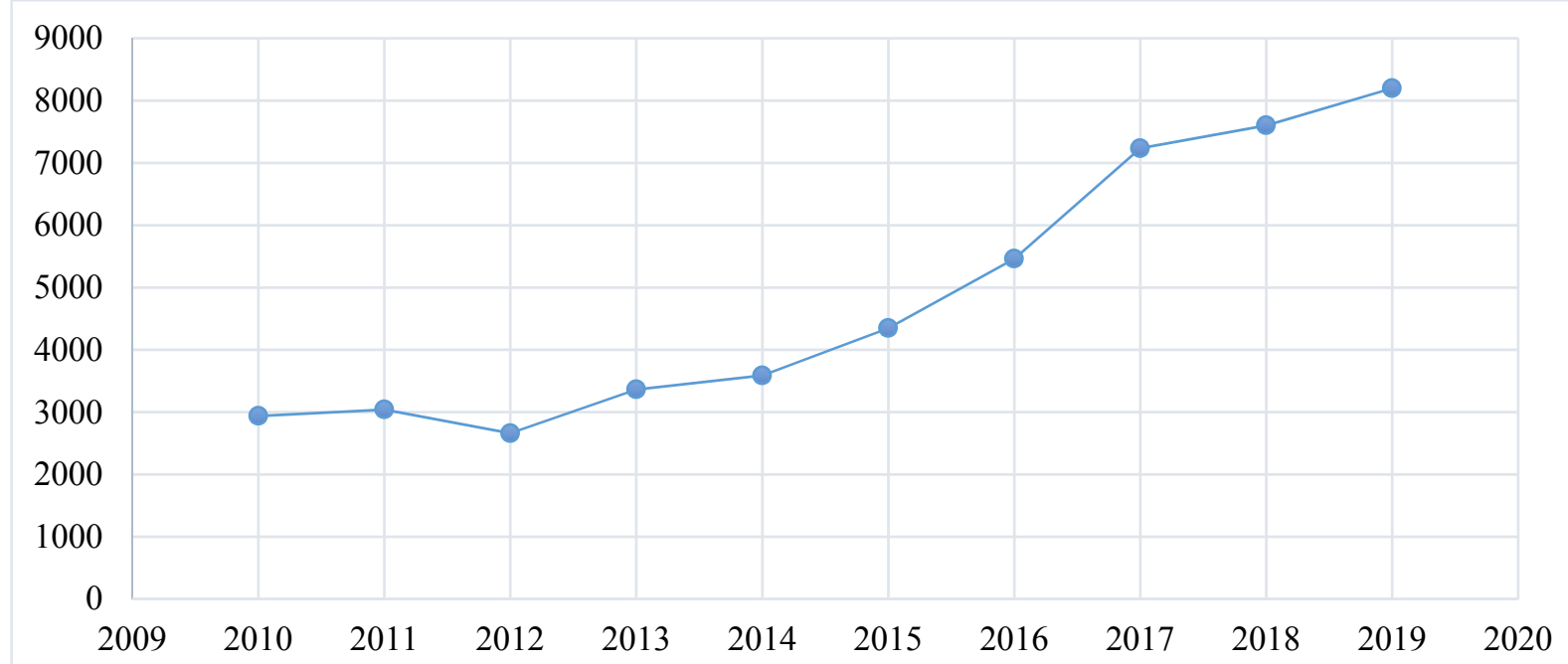

Fig. 8. Average price of milk sold by enterprises, UAH / ton [2]

Calculation of correlation

Table 2

\begin{tabular}{|c|c|c|c|c|c|c|c|}
\hline Year & $\begin{array}{c}\text { Milk, } \\
\text { thouthand } \\
\text { tons }\end{array}$ & $\begin{array}{c}\text { The average price } \\
\text { of milk sold, } \\
\text { UAH / ton by } \\
\text { enterprises }\end{array}$ & $\left|X_{i}-\bar{X}\right|$ & $\left|Y_{i}-\bar{Y}\right|$ & $\begin{array}{c}\left|X_{i}-\bar{X}\right| \times \\
\left|Y_{i}-\bar{Y}\right|\end{array}$ & $\left|X_{i}-X\right|^{2}$ & $\left|Y_{i}-Y\right|^{2}$ \\
\hline 2010 & 11248,5 & -515 & 1905 & -980643 & 264947 & -515 & 3629635 \\
\hline 2011 & 11086 & -352 & 1802 & -634810 & 124066 & -352 & 3248141 \\
\hline 2012 & 11377,6 & -644 & 2182 & -1404618 & 414517 & -644 & 4759640 \\
\hline 2013 & 11488,2 & -754 & 1480 & -1116451 & 569165 & -754 & 2189986 \\
\hline 2014 & 11132,8 & -399 & 1255 & -500966 & 159225 & -399 & 1576180 \\
\hline 2015 & 10615,4 & 118 & 497 & 58778 & 14011 & 118 & 246572 \\
\hline 2016 & 10381,5 & 352 & -618 & -217682 & 124094 & 352 & 381850 \\
\hline 2017 & 10280,5 & 453 & -2390 & -1083379 & 205454 & 453 & 5712769 \\
\hline 2018 & 10064 & 670 & -2759 & -1847587 & 448592 & 670 & 7609543 \\
\hline 2019 & 9663,2 & 1071 & -3354 & -3591056 & 1146120 & 1071 & 11251597 \\
\hline
\end{tabular}

Developed by the authors based on materials: [2].

$\sigma_{x}=\sqrt{\frac{\sum\left|X_{i}-X\right|^{2}}{10}}=\sqrt{\frac{3470190,8610}{10}}=589,0832591$

$\sigma_{y}=\sqrt{\frac{\sum\left|Y_{i}-Y\right|^{2}}{10}}=\sqrt{\frac{40605912,1840}{10}}=2015,090871$

$r=\frac{\frac{1}{n} \times \Sigma|X-\bar{X}| \times|Y-\bar{Y}|}{\sigma_{x} \times \sigma_{y}}=\frac{\frac{1}{10} \times(-11318413,9720)}{589,0832591 \times 2015,090871}=-$ 0,953485862

After conducting a correlation analysis, we found that the price depends entirely on the volume of production, although it could be assumed that a decrease in volume would increase both the quality and, consequently, the price. However, a negative, very high (-95.4\%) correlation coefficient was obtained. This means that the increase in the price of dairy products is directly related to the reduction in the number of livestock, and, as a consequence, the reduction in milk production $[22,23]$. Therefore, the intensification of production and increase in the number of livestock will reduce the price and, as a consequence, increase the competitiveness of Ukrainian dairy products on world markets.

However, the environmental aspect of the issue needs to be considered, as the dairy industry may become an accelerator of global warming. There is evidence that 1 cow emits about 4 liters of methane per day, so we can assume that the dairy industry in Ukraine in 2020 produced about 110 billion liters of methane. Although more cars with carbon dioxide emissions are now blamed for warming, methane is 20 times more dangerous [5].

Increasing labor intensity in the field of animal husbandry will also help to increase competitiveness. To do this, we compare the dynamics of labor productivity in crop production and animal husbandry and understand how viable and competitive animal husbandry is. 


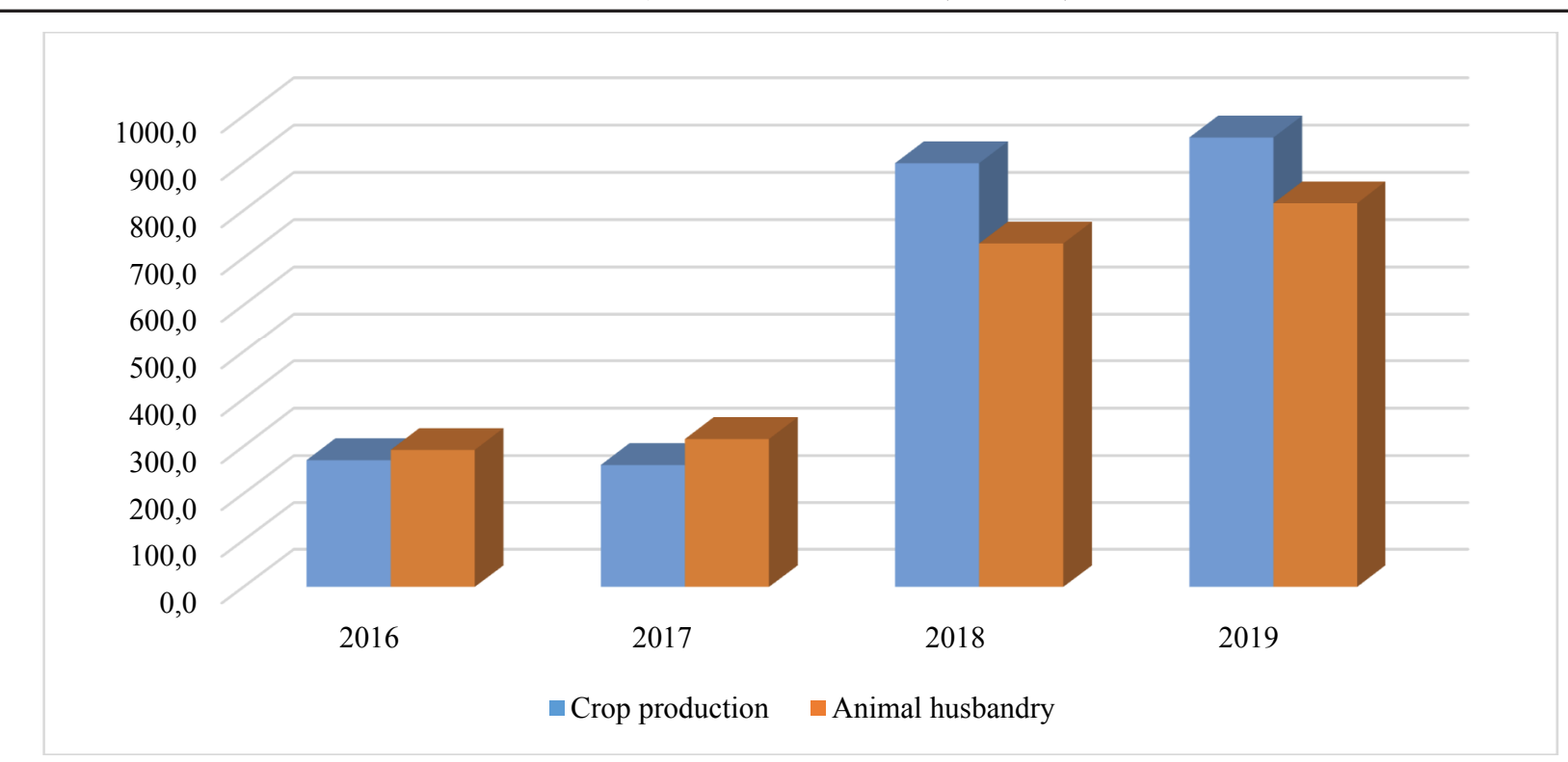

Fig. 9. Productivity, thousand UAH per employee [2]

This infographic shows that if earlier animal husbandry was more productive, then from 2018 the situation has changed. These indicators could be affected by rising grain prices in foreign markets and, as a consequence, rising prices for animal feed. The methodology of calculation of the State Statistics Service has also changed, because in 2016-17 the base year was 2010, and accordingly in 2018-19 - 2015.

The competitiveness of the national economy as a whole is affected not only by the quality of technology, demand for products in foreign and domestic markets, macroeconomic climate, but also effective government policy to support this industry. Legal regulation, government incentives, which are used in conjunction with the policy of "reasonable protectionism" facilitate the situation of the industry both within the country and ensure competitiveness when entering the foreign market. Thus, state support is declared in Article 16 of the Law of Ukraine "On Milk and Dairy Products" of 2004. In particular, this law provides for the support of selection work, as well as the provision of soft loans, grants and more. However, since 2010, the nature of subsidy policy has changed, which has directly affected the profitability of production.

\section{Conclusions.}

After conducting this study, it was found that the Ukrainian dairy industry is able to compete in world commodity markets. Global demand for these products is projected to grow, which is why the focus on dairy products in domestic production and exports will allow Ukraine to increase competitiveness.

Prospects for the development of the industry we propose to increase exports to partner countries (Kazakhstan, Moldova, Kyrgyzstan, the Middle East), as Ukraine is able to compete in most regional markets, except Europe.

However, in the future the situation may change radically due to the environmental component of milk and dairy production. Therefore, Europe may begin to reduce its own production and will be forced to import dairy products.

Given the overall reduction in the capacity of the dairy industry in Ukraine, producers need to choose the path of the most effective development through the intensification of production and the introduction of new technologies. As Ukraine, like most European countries, strives for climate neutrality, the production of environmentally friendly products is the most important area.

As an alternative, we can offer the development of eco-farms - small farms with a well-established material and technical base, which would not pollute the environment. The main buyers of such products could be including EU countries. However, the selling price of dairy products may be too high for the domestic buyer.

\section{КОНКУРЕНТОСПРОМОЖНІСТЬ ПРОДУКЦІї МОАОЧНОЇ ПРОМИСАОВОСТІ УКРАЇНИ: СУЧАСНИЙ СТАН ТА ПЕРСПЕКТИВИ РОЗВИТКУ}

Іщенко Марія Охександрівна, старший викладач, кафедра міжнародних економічних відносин імені Артура Голікова Харківського національного університету імені В. Н. Каразіна, пц. Свободи, 6, Харків, Україна, 61022. e-mail: lazarchuk@karazin.ua, ORCID: 0000-0003-4275-9579

Гончар Данимо Русланович, студент, кафедра міжнародних економічних відносин імені Артура Голікова Харківського національного університету імені В. Н. Каразіна, пл. Свободи, 6, Харків, Україна, 61022, e-mail: gonchar.danylo@gmail.com, ORCID: 0000-0003-4292-6322 
В статті розглянуто сучасний стан, тенденції та проблеми розвитку молочної промисловості України в сучасних умовах. Предметом дослідження в статті $є$ конкурентоспроможність української молочної продукції на глобальних ринках. Мета полягає у виявценні порівняльних переваг молочної промисловості України та визначенні перспектив для ії подальшого розвитку. Завдання: дослідити сучасний стан і динаміку виробництва, світових цін, попиту, експорту молочної продукції в Україні та світі, визначити порівняльні переваги України в молочній галузі на основі розрахунку індексу Баласса, розглянути екологічну сторону розвитку галузі. У статті використовуються загальнонаукові методи: системний аналіз - для визначення конкурентоспроможності молочної промисловості України; історичний метод - для відстеження тенденцій світового та українського ринку молочної продукції; кореляційний аналіз - для визначення взаємозв'язку цін на внутрішньому ринку, статистичний метод - дмя відображення кількісних показників та ін. Отримані такі результати: на основі проведеного дослідження виявцені тенденції зниження обсягів виробництва та експорту молочної продукції, виявлені порівняльні переваги молочної галузі України на більшості регіональних ринків світу крім європейського та запропоновані шляхи подальшого розвитку галузі відповідно до сучасних викликів в глобалізованому світі. Висновки: українська молочна галузь здатна конкурувати на світових товарних ринках, перспективними напрямами розширення експорту може стати Казахстан, Молдова, Киргизстан, країни Близького Сходу. 3 огляду на загальне скорочення потужностей молочної галузі в Україні виробникам пропонується сконцентруватися на інтенсифікації виробництва і впровадження новітніх технологій, враховуючи екологічну складову.

КАючові слова: молочна промисловість, експорт, конкурентоспроможність, виробництво молока, молочна галузь, порівняльні переваги, екологія.

\section{КОНКУРЕНТОСПОСОБНОСТЬ ПРОДУКЦИИ МОАОЧНОЙ ПРОМЫШАЕННОСТИ УКРАИНЫ: СОВРЕМЕННОЕ СОСТОЯНИЕ И ПЕРСПЕКТИВЫ РАЗВИТИЯ}

Ищенко Мария Амександровна, старший преподаватель, кафедра международных экономических отношений имени Артура Голикова Харьковского национального университета имени В. Н. Каразина, пл. Свободы, 6, Харьков, Украина, 61022. e-mail: lazarchuk@karazin.ua, ORCID: 0000-0003-4275-9579

Гончар Даниим Русманович, студент, кафедра международных экономических отношений имени Артура Голикова Харьковского национального университета имени В. Н. Каразина, пл. Свободы, 6, Харьков, Украина, 61022, e-mail: gonchar.danylo@gmail.com, ORCID: 0000-0003-4292-6322

В статье рассматривается современное состояние, тенденции и проблемы развития молочной отрасли Украины в современных условиях. Предметом исследования в статье является конкурентоспособность украинской молочной продукции на мировых рынках. Цель состоит в выявлении сравнительных преимуществ молочной промышленности Украины и определении перспектив для ее дальнейшего развития. Задача: исследовать современное состояние и динамику производства, мировых цен, спроса, экспорта молочной продукции в Украине и мире, определить сравнительные преимущества Украины в молочной отрасли на основе расчета индекса Баласса, рассмотреть экологическую сторону развития отрасли. В статье используются общенаучные методы: системный анализ - для определения конкурентоспособности молочной промышленности Украины; исторический метод - для отслеживания тенденций мирового и украинского рынка молочной продукции; корреляционный анализ - для определения взаимосвязи цен на внутреннем рынке, статистический метод - для отражения количественных показателей и др. Были получены следующие результаты: на основе проведенного исследования выявлены снижения объемов производства и экспорта молочной продукции, выявлены сравнительные преимущества молочной отрасли Украины на большинстве региональных рынков мира кроме европейского и предложены пути дальнейшего развития отрасли в соответствии с современными вызовами в глобализированном мире. Выводы: украинская молочная отрасль способна конкурировать на мировых товарных рынках, перспективными направцениями расширения экспорта может стать Казахстан, Молдова, Кыргызстан, страны Ближнего Востока. Учитывая общее сокращение мощностей молочной отрасли в Украине, производителям предлагается сконцентрироваться на интенсификации производства и внедрении новейших технологий, учитывая экологическую составляющую.

Кмючевые слова: молочная промышленность, экспорт, конкурентоспособность, производство молока, молочная отрасль, сравнительные преимущества, экология.

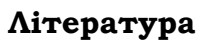

1. Аналітика та структура імпорту/експорту молочної продукції (за інформацією Національної асоціації молочників України "Укрмолпром"). 29 Міжнародна виставка "Обладнання та технологї для харчової промисловостін. URL: https://inprodmash.ua/analitika-ta-struktura-importu-ekspo/ (дата звернення: 21.11.2020).

2. Державна служба статистики України : веб-сайт. URL: http://www.ukrstat.gov.ua/ (дата звернення: 21.11.2020). 
3. Джеджула В. В., Єпіфанова І. Ю., Дзюбко М. Ю. Напрями підвищення ефективності діяльності підприємств молочної галузі. Iнвестииї̈: практика та досвід. 2018. №11. C. 12-14. URL: http://www.investplan.com.ua/pdf/11_2018/4.pdf (дата звернення: 21.12.2020).

4. Експорт молока та молочних продуктів до ЄС: перші кроки. Євроінтеграційний портал : вебсайт. URL: http://eu-ua.org/eksport-yes/moloka-ta-molochnoi-produktsii (дата звернення: 21.11.2020).

5. Защита климата: как заставить коров производить меньше метана. DW : веб-сайт. URL: http:/ / surl.li/ohwq (дата звернення: 21.11.2020)

6. Индекс продовольственных цен ФАО. Продовольственная и сельскохозяйственная организация Объединенных Наиий : веб-сайт. URL: http://www.fao.org/worldfoodsituation/foodpricesindex/ru/ (дата звернення: 21.11.2020).

7. Мостенська Т. $\Lambda$. Вплив ціни на конкурентоспроможність продукціїі на ринку молока / Т. $\Lambda$. Мостенська, М. П. Сичевський. Наукові праиі Наиіонального університету харчових технологій. 2013. № 52. URL: http://nbuv.gov.ua/UJRN/Npnukht_2013_52_22. (дата звернення: 21.12.2020).

8. Скопенко Н. С., Бовкун А. О. Сучасний стан та тенденції розвитку молочної галузі України. $\begin{array}{llllll}\text { Продукты } \quad \& & \text { Ингридиенты. } & 2011 . & \text { № } & 04 . & \text { URL: }\end{array}$ http://dspace.nuft.edu.ua/bitstream/123456789/30309/1/dairy\%20industry.pdf. (дата звернення: 21.12.2020).

9. Статистика експорту молочної продукції. УкрМолПром : веб-сайт. URL: http://www.ukrmolprom.kiev.ua/ua/ (дата звернення: 21.11.2020).

10. Тарасова Ю. А. Стан та перспективи розвитку молочної галузі України. Вісник соиіальноекономічних дослідженъ. 2017. № 1. С. 149-156. - URL: https://doi.org/10.33987/vsed.1(62).2017.149-156 (дата звернення: 21.12.2020).

11. Хворост Т. В. Розвиток світового та національного ринку молочної продукції. Ефективна економіка. 2014. № 11. URL: http://www.economy.nayka.com.ua/?op=1\&z=3519 (дата звернення: 21.12.2020).

12. Чередніченко О, Пащенко О. Економічні аспекти виробництва та споживання молока й молочних продуктів Agricultural and resource economics: international scientific e-journal. 2018. Vol. 4. № 1. C. $162-173$. URL: https://doi.org/10.22004/ag.econ.270310 (дата звернення: 21.12.2020).

13. Alexandr Tarasevych. Dairy and products annual report. USDA : website. URL: https: / / apps.fas.usda.gov/ newgainapi/api/Report/DownloadReportByFileName?fileName=Dairy\%20and\%2 OProducts\%20Annual_Kyiv_Ukraine_10-15-2020 (дата звернення: 21.11.2020).

14. Babenko, V.A. Formation of economic-mathematical model for process dynamics of innovative technologies management at agroindustrial enterprises. Actual Problems of Economics, Vol. 139, Issue 1, 2013. Pp. 182-186.

15. Babenko, V. O. Modeling of factors influencing innovation activities of agricultural enterprises of Ukraine. Scientific Bulletin of Polissia, no. 1 (9), p. 2, 2017. Pp. 115-121. https://doi.org/10.25140/24109576-2017-2-2(10)-115-121

16. Gateway to dairy production and products. Food and agricultural organisation of the UN: website. URL: http: / /www.fao.org/dairy-production-products/production/en/ (дата звернення: 21.11.2020).

17. Frick F., Sauer J. Deregulation and Productivity: Empirical Evidence on Dairy Production. American Journal of Agricultural Economics, vol. 100, is. 1, pp. 354-378. URL: https://doi.org/10.1093/ajae/aax074 (дата звернення: 21.12.2020).

18. Merchandise: Intra-trade and extra-trade of country groups by product, annual. UNCTADstat: website. https://unctadstat.unctad.org/wds/TableViewer/tableView.aspx?ReportId=24397 (дата звернення: 21.11.2020).

19. Pronko, L. ., Kolesnik, T. ., \& Samborska, O. Ukraine Dairy Market: State and Prospects of Development. European Journal of Sustainable Development. Vo.9. no1. pp. 243-252. URL: https://doi.org/10.14207/ ejsd.2020.v9n1p243(дата звернення: 21.12.2020).

20. Shorikov, A.F., Babenko, V.A. Optimization of assured result in dynamical model of management of innovation process in the enterprise of agricultural production complex. Economy of Region, Issue 1, 2014. Pp. 196-202. http://dx.doi.org/10.17059/2014-1-18

21. Ukraine: Dairy Sector. Clal : website. https://www.clal.it/en/?section=stat_ucraina (дата звернення: 21.11.2020).

22. Ukraine: $\quad$ profile. OEC $\quad: \quad$ website. $\quad$ URL: https:/ / oec.world/en/profile/country/ukr?depthSelector1=HS4Depth\&yearSelector1=exportGrowthYear24 (дата звернення: 21.11.2020).

23. Varchenko O., Radko V., Rudych O., Svynous I., Tkachenko, K. Risks of dairy farming in Ukraine and ways of their minimization and neutralization. Agricultural Science and Practice. no. 6(1). pp. 41-59. URL: https://doi.org/10.15407/agrisp6.01.041 (дата звернення: 21.12.2020).

\section{References}

1. Analysis and structure of exports and imports of dairy products [Analityka ta struktura importu/eksportu molochnoji produkciji]. Available at: https://inprodmash.ua/analitika-ta-strukturaimportu-ekspo/ [in Ukrainian] (accessed 21 November 2020). 
2. Ukraine National Statistical office [Derzhavna sluzhba statystyky Ukrajiny]. Available at: http://www.ukrstat.gov.ua/ [in Ukrainian] (accessed 21 November 2020).

3. Dzhedzhula V. V., Yepifanova I. Yu. \& Dziubko M. Yu. (2018) Ways of developing the efficiency of dairy facilites [Napriamy pidvyshchennia efektyvnosti diialnosti pidpryiemstv molochnoi haluzi]. Investment: practice and experience, 2018, no. $11 . \quad$ pp. $12-14 . \quad$ Available at: URL: http://www.investplan.com.ua/pdf/11_2018/4.pdf (accessed 21 December 2020)

4. Milk and dairy products exports to EU [Eksport moloka ta molochnykh produktiv do JeS: pershi kroky]. European integration portal. Available at: http://eu-ua.org/eksport-yes/moloka-ta-molochnoiproduktsii (accessed 21 November 2020).

5. Climate protection: how make cows produce less gas [Zashhyta klymata: kak zastavytj korov proyzvodytj menjshe metana]. Available at: http://surl.li/ohwq (accessed 21 November 2020).

6. FAO Food Price Index. The Food and Agriculture Organization of the United Nations [Indeks prodovol'stvennykh tsen FAO. Prodovol'stvennaya i sel'skokhozyaystvennaya organizatsiya Ob"edinennykh Natsiy]. Available at: http://www.fao.org/worldfoodsituation/foodpricesindex/ru/ [in Russian] (accessed 21 November 2020).

7. Mostenska T. Effect of prices on competitiveness of product on the market milk [Vplyv Tsiny na Konkurentospromozhnist Produktsiii Na Rynku Moloka] / T. Mostenska, N. Sychevskii. Available at: URL: http://dspace.nuft.edu.ua/jspui/handle/123456789/19731 (accessed 21 December 2020).

8. Skopenko, N. S., Bovkun, A. O. Current status and development trends of the dairy industry in Ukraine [Suchasnyi stan ta tendentsii rozvytku molochnoi haluzi Ukrainy]. Available at: http://dspace.nuft.edu.ua/bitstream/123456789/30309/1/dairy\%20industry.pdf (accessed 21 December 2020).

9. Statystyka eksportu molochnoji produkciji [Dairy exports statistics]. Available at: http://www.ukrmolprom.kiev.ua/ua/ [in Ukrainian] (accessed 21 November 2020).

10. Khvorost T. V. Development of the world's and national dairy markets [Rozvytok svitovogho ta nacionaljnogho rynku molochnoji produkciji]. Efektyvna ekonomika. 2014, 11. [in Ukrainian] http: / / www.economy.nayka.com.ua/?op=1\&z=3519

11. Tarasova Yu. Status and prospects of development of Ukrainian dairy industry [Stan ta perspektyvy rozvytku molochnoi haluzi Ukrainy], Socio-economic research bulletin, Odessa National Economic University, Odessa, no. 1 (62), pp. 149-156. [in Ukrainian] https://doi.org/10.33987/vsed.1(62).2017.149-156

12. Cherednichenko O., Pashchenko O. Economic aspects of production and consumption of milk and dairy products. Agricultural and Resource Economics: International Scientific E-Journal, 4(1), $162-173$. https://doi.org/10.22004/ag.econ.270310

13. Tarasevych A. Dairy and products annual report. USDA. Available at: https://apps.fas.usda.gov/newgainapi/api/Report/DownloadReportByFileName?fileName=Dairy $\% 20$ and $\% 2$ OProducts\%20Annual_Kyiv_Ukraine_10-15-2020 (accessed 21 November 2020).

14. Babenko, V.A. (2013). Formation of economic-mathematical model for process dynamics of innovative technologies management at agroindustrial enterprises. Actual Problems of Economics, Vol. 139, Issue 1, pp. $182-186$.

15. Babenko, V. O. (2017). Modeling of factors influencing innovation activities of agricultural enterprises of Ukraine. Scientific Bulletin of Polissia, no. 1 (9), p. 2, pp. 115-121. https://doi.org/10.25140/2410-95762017-2-2(10)-115-121

16. Gateway to dairy production and products : Food and agricultural organisation of the UN. Available at: http://www.fao.org/dairy-production-products/production/en/ (accessed 21 November 2020).

17. Frick F., Sauer J. Deregulation and Productivity: Empirical Evidence on Dairy Production. American Journal of Agricultural Economics, vol. 100, is. 1, pp. 354-378. https://doi.org/10.1093/ajae/aax074

18. Merchandise: Intra-trade and extra-trade of country groups by product, annual. Available at: https://unctadstat.unctad.org/wds/TableViewer/tableView.aspx?ReportId=24397 (accessed 21 November 2020).

19. Pronko L., Kolesnik T., Samborska O. Ukraine Dairy Market: State and Prospects of Development. European Journal of Sustainable Development. Vo.9. no1., pp. $243-252$. https://doi.org/10.14207/ejsd.2020.v9n1p243

20. Shorikov, A.F., Babenko, V.A. (2014). Optimization of assured result in dynamical model of management of innovation process in the enterprise of agricultural production complex. Economy of Region, Issue 1, pp. 196-202. http://dx.doi.org/10.17059/2014-1-18

21. Ukraine: Dairy Sector. Available at: https://www.clal.it/en/?section=stat_ucraina (accessed 21 November 2020).

22. Ukraine:

profile.

Retrived

from:

https://oec.world/en/profile/country/ukr?depthSelector1=HS4Depth\&yearSelector1=exportGrowthYear24 (accessed 21 November 2020).

23. Varchenko O., Radko V., Rudych O., Svynous I., Tkachenko, K. Risks of dairy farming in Ukraine and ways of their minimization and neutralization. Agricultural Science and Practice. no. 6(1). pp. 41-59. https://doi.org/10.15407/agrisp6.01.041 